\title{
Verbal Capability as A Variable Mediator The Effect Between Discipline Techniques And Mother Ability To Give Commands To Traditional Games On Down Syndrome Children's Compliance
}

\author{
Natris Idriyani ${ }^{1}$, Neneng Tati Sumiati ${ }^{2}$, Puti Febrayosi ${ }^{3}$, Solicha ${ }^{4}$ \\ \{natris.idriyani@uinjkt.ac.id; neneng.tati@uinjkt.ac.id; putifeb0602@gmail.com\} \\ Psychology Faculty, UIN Syarif Hidayatullah Jakarta, Indonesia
}

\begin{abstract}
The purpose of this study was to obtain a discipline technique model and the ability of mothers to give orders after attending traditional game training mediated by children's verbal abilities and on the level of adherence in children with down syndrome in Indonesia. The method used in this study is a causal relationship. Respondents in this study were children with Down syndrome with their mothers. The research measuring instrument uses a scale of discipline techniques, the scale of compliance and maternal ability questionnaire. The verbal ability is measured through Weschler Preschool Primary Scale Intelligence, subtest picture naming and receptive vocabulary Data analysis techniques use path analysis techniques. The number of respondents was 81 pairs of mothers and children with Down syndrome. Based on the results of the study obtained a discipline technique model and the ability of the mother after attending the seminar the benefits of traditional games affect the self-adherence of children with Down syndrome, which is mediated by children's verbal abilities are fit with empirical data.
\end{abstract}

Keywords: Keywords: Verbal Capability, Discipline Techniques, Traditional Games, Down Syndrome, Children's Compliance

\section{Introduction}

Children born with chromosomal abnormalities number around 3,000 to 5,000 people per year. Down syndrome - the next one called ds - is one of the chromosomal abnormalities with a prevalence of one in 800 to 1,200 live births worldwide. The number of ds cases in Indonesia is around 300,000 cases and constitutes $15 \%$ of the world's ds cases. Figures are significant for the indonesian population which constitutes $3.7 \%$ of the world's population ("birth in south-east asia a public health challenge," n.d.).

Individuals with ds have more emotional and behavioral problems than individuals with a typical development [1]. In early childhood and school age ds often featured externalizing behaviors such as hyperactivity, impulsivity, tantrums, agitation, stubbornness, disruptiveness/ argumentativeness, repetitive movements and dysregulation [2]. Some research results show that the most prominent behavioral problems in ds other than emotional problems are conduct disorder, with non-compliance (non-compliance), aggression, and hyperactivity [3]. These studies are in line with the results of research in indonesia conducted by Sumiati [4] which 
shows that $50 \%$ of parents of children with ds assess behavioral problems in the high category. These behavioral problems include aggressive, impulsive and unruly or difficult to obey the rules / instructions given. Parents and teachers report high rates of non-compliance with ds children compared to other children [3]. Ducharme and schecter interpret compliance as a key behavior that can increase involvement in prosocial behavior and other behaviors and are described as obedient behavior towards something [5]. Thus compliance is an important behavior possessed by children including children with ds.

A child's compliance with an instruction can be caused by various factors. One of them is the way parents discipline. The technique of applying parental discipline is the way parents apply the applicable rules, where there are three techniques, namely; power assertion, induction and love withdrawal [6].

The results of research conducted by Sabrina [7] showed that about $44 \%$ of parents of children with special needs used the power assertion technique. The findings of the research conducted by Sumiati [4] show that there is no significant relationship between the type of application of discipline with behavioral problems (aggressive, impulsive and noncompliance) in ds children. This finding is not in line with the theory, thus giving rise to allegations that there are other factors either directly or indirectly affecting a child's compliance.

In ds children, it is suspected that the level of adherence is not only influenced by the discipline techniques applied by parents, but also the possibility of how much the child understands the instructions given. This condition is related to the limitations of ds, namely limitations in the cognitive area, especially in aspects of language skills. Language becomes a medium for learning and knowing how to regulate behavior [8]. In a study by Cuskelly and colleagues [9], it was found that $28.1 \%$ of participants with ds did

not understand the assignment given. The findings of the study by Cuskelly and his colleagues reflect the importance of receptive language in complying with the rules given.

Another factor that can be done to improve compliance is through intervention. Interventions that deal with non-compliance with children usually rely on strategies rooted in behavioral analysis. Some of the most studied treatments, among others, are parent-child interaction therapy; and training of parents who apply a combination of behavioral strategies such as praise, contingent and time-out, antecedent strategies such as regulation and modification of instructions, and outage procedures such as planned neglect [5]. Other therapies studied to deal with disruptive behavior (one form of non-compliant behavior belonging to externalizing behavior) are play therapy. Ritzi, Ray, and Schumann [10] show that play therapy in ds children aged six to nine years is significantly effective in changing externalizing behaviors such as non-adherent behavior. However, studies on play therapy in atypical children such as Down Syndrome (ds) are still very limited.

Play therapy is a therapeutic method that includes dynamic interpersonal relationships between children and children, or between children and parents, or between children and therapists, where through certain game activities children can express and explore themselves (feelings, thoughts, experience and behavior comfortably so as to optimize growth and development [11]. According to Joseph Chilton Pearce, playing is the most appropriate medium to teach many things to children. The role of toys in children with special needs according to Emily Jean Davidson, clinical director at the Down Syndrome Program at Boston Children's Hospital, United States, is also as important as other children. Especially for children with Down Syndrome (ds), it is recommended to provide a type of toy that is useful for sharpening their interaction skills and language skills and basic logic of mathematics. 
Playing is very important for the health of children who are in the development stage in a better direction. This is also very important for children who have special handling, including down syndrome. By playing, children get the opportunity to explore the environment. The results of the study show that through playing between mothers and children, the expression of negative affect (including non-compliance) in ds children can be significantly reduced [12]. The findings of the study by Vieillevoye and Nader-Grosbois [13] showed that pretending to play (pretend play) significantly improved self-regulation ability in both normal and children with intellectual disability (including ds).

The results of these studies show that play therapy is quite effective in directing the behavior of children, including children with ds. It's just that, the role of play is less realized by parents. In general, parents focus more on therapies carried out by the therapist. Parents rely more on behavioral therapy carried out by psychologists to deal with child behavior problems, including problems with child disobedience. Parents also rely more on speech therapy or occupational therapy by therapists to improve their children's communication or motor skills.

The therapeutic efforts that have been carried out by parents reflect that basically, they realize the limitations that their ds children have. The most obvious limitation is in communication. Some studies show that ds has limitations in terms of verbal abilities. Singh, Iacono, and Gray [14] revealed that children with ds have the potential to maintain a way of communicating and playing with the symbol for a long time. These findings show the need to set targets to improve their communication skills.

Playing is very important for the health of children who are in the development stage in a better direction. This is also very important for children who have special handling, including down syndrome. By playing, children get the opportunity to explore the environment. The results of the study show that through playing between mothers and children, the expression of negative affect (including non-compliance) in ds children can be significantly reduced [12]. The findings of the study by Vieillevoye and NaderGrosbois [13] showed that pretending to play (pretend play) significantly improved selfregulation ability in both normal and children with intellectual disability (including ds).

The results of these studies show that play therapy is quite effective in directing the behavior of children, including children with ds. It's just that, the role of play is less realized by parents. In general, parents focus more on therapies carried out by the therapist. Parents rely more on behavioral therapy carried out by psychologists to deal with child behavior problems, including problems with child disobedience. Parents also rely more on speech therapy or occupational therapy by therapists to improve their children's communication or motor skills.

The therapeutic efforts that have been carried out by parents reflect that basically, they realize the limitations that their ds children have. The most obvious limitation is in communication. Some studies show that ds has limitations in terms of verbal abilities. Singh, Iacono, and Gray [14] revealed that children with ds have the potential to maintain a way of communicating and playing with the symbol for a long time. These findings show the need to set targets to improve their communication skills.

One type of game that can be used in play therapy is traditional games, such as jingkat-jingkat letters. In the game, the child must understand and be willing to obey the rules given along with the consequences he will receive if he violates. The child will be given a series of instructions that must be followed. The child's understanding of the instructions given is closely related to his verbal abilities. Especially in ds children, where verbal ability is one of the limitations it has. The failure of children to comply with the 
rules can be caused by a lack of understanding of the rules of the game rather than the desire to disobey the rules.

Considering the important role of playing and the application of parental discipline techniques as well as verbal abilities possessed by ds children, this study aims to examine more about the application of disciplinary techniques and play therapy to ds child adherence through verbal abilities.

\section{Problem Statement}

This study focuses on proving the influence of parental discipline techniques, the ability of mothers to give orders in traditional games and children's verbal ability to adhere to orders in ds children. The research questions proposed are as follows:

1. What are the techniques of parental discipline and the ability of the mother to give orders after taking part in traditional game training mediated by children's verbal abilities and on the level of adherence to children with ds in Indonesia - fit with data?

2. Does the technique of parental discipline and the ability of the mother to give orders after attending traditional game training mediated by children's verbal abilities influence the level of adherence to children with ds in Indonesia?

3. Is there a significant influence between parental discipline techniques on the level of adherence to children with ds in Indonesia?

4. Is there a significant influence on the ability of the mother to give orders (after attending traditional game training) to adherence through the verbal abilities of children with ds in Indonesia

\section{Research Framework}

Parental discipline techniques are considered to have a significant influence on the level of child compliance. The discipline technique concept uses theory from Hoffman, et al. The findings in the study of Rodriquez [15] show that parenting style is related to children's noncompliance behavior. Schuele and Prinz [16] explained that the way parents respond to their children's behavior can influence the level of adherence to children. This is due to the quality of orders (requests) from parents where requests, orders were given clearly, calmly and specifically will increase compliance [16]. Parents who are taught to give orders effectively through several pieces of training will improve children's needs. In this study, the intervention provided was a way of giving orders through traditional games assumed to increase the level of compliance.

\section{Research Methods}

The method used in the study is a causal relationship. The number of respondents netted 119 pairs of mothers and children with Down syndrome. The study sample used in this study amounted to 81 pairs of mothers and children with Down syndrome. The sampling technique used is non-probability sampling with purposive sampling technique. 
The measuring instruments used in this study were discipline technique scale, maternal self-efficacy questionnaire, and WPPSI sub receptive vocabulary test and picture naming. Data analysis techniques in this study used path analysis using M-Plus software.

\section{Result}

Hypothesis test results with path analysis technique obtained Chi-Square value = $11,410, \mathrm{df}=8, \mathrm{P}$-value $=0.1795, \mathrm{RMSEA}=0.073$ with confidence interval 0,000 to $0.160, \mathrm{CFI}=0.907$. The value of P-Value is above 0.05 , the RMSEA that is generated is still above 0.05 , but it can be seen from the confidence interval generated, and CFI approaching 1 . Of all the indexes that are produced meet the requirements, the model can be declared fit. Thus, the model in which power assertion, love withdrawal, and induction are part of parental discipline techniques, and maternal self efficacy after attending a seminar on the benefits of traditional games affects the self-adherence of down syndrome children, where children's verbal abilities are picture naming and receptive vocabulary as variables the mediator can be declared fit. The picture of the model in question can be seen in the picture below:

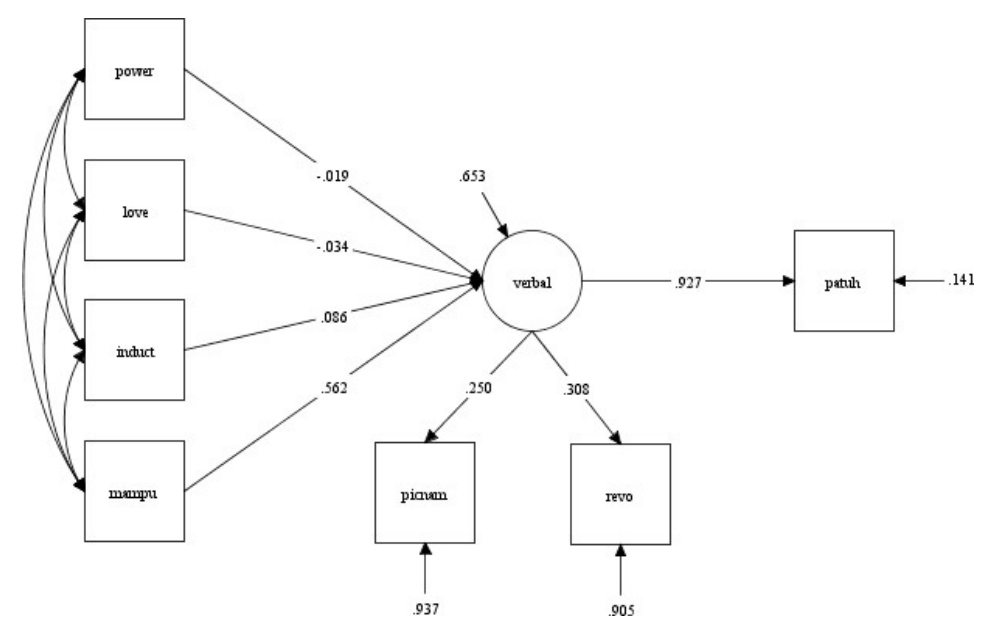

Fig. 1: Fit Model research 
Table 1. IV Influence Coefficient (parental discipline techniques and maternal ability) on DV (Self Compliance) where Verbal Ability as Mediator

\begin{tabular}{|c|c|c|c|c|c|}
\hline $\begin{array}{l}\text { Variable } \\
\text { Verbal } \\
\text { ability By }\end{array}$ & $\begin{array}{l}\text { Coeffici } \\
\text { ent }\end{array}$ & S.E. & t value & $\begin{array}{l}\text { Two-Tailed } \\
\text { P-Value }\end{array}$ & Sig. \\
\hline $\begin{array}{l}\text { Picture } \\
\text { Naming }\end{array}$ & 0.250 & 0.121 & 2.071 & 0.038 & $\sqrt{ }$ \\
\hline $\begin{array}{l}\text { Receptive } \\
\text { Vocabulary }\end{array}$ & 0.308 & 0.132 & 2.335 & 0.020 & $\sqrt{ }$ \\
\hline $\begin{array}{l}\text { Variable } \\
\text { Verbal } \\
\text { ability } \\
\end{array}$ & $\begin{array}{l}\text { Coeffici } \\
\text { ent }\end{array}$ & S.E. & t value & $\begin{array}{l}\text { Two-Tailed } \\
\text { P-Value }\end{array}$ & Sig. \\
\hline $\begin{array}{l}\text { Power } \\
\text { assertion }\end{array}$ & -0.019 & 0.107 & -0.182 & 0.856 & $\mathrm{X}$ \\
\hline $\begin{array}{l}\text { Love } \\
\text { withdrawal }\end{array}$ & -0.034 & 0.108 & -0.317 & 0.751 & $\mathrm{X}$ \\
\hline Induction & 0.086 & 0.114 & 0.754 & 0.451 & $\mathrm{X}$ \\
\hline $\begin{array}{l}\text { Mother } \\
\text { ability }\end{array}$ & 0.562 & 0.121 & 4.631 & 0.000 & $\sqrt{ }$ \\
\hline $\begin{array}{l}\text { Self } \\
\text { obedience }\end{array}$ & & & & & \\
\hline $\begin{array}{l}\text { Verbal } \\
\text { ability }\end{array}$ & 0.927 & 0.180 & 5.145 & 0.000 & $\sqrt{ }$ \\
\hline
\end{tabular}

Note: $\sqrt{ }$ : siginificant; $x$ : not significant

Of the four variables, there is one variable that has a significant effect on verbal ability, namely the ability of the mother after getting training on the benefits of traditional games, while the explanation is as follows:

1. Power assertion has a negative coefficient of -

0.019 and a value of $t=-0.182$. These results indicate that the power assertion is not significant for the self-compliance of down syndrome children. Thus this result cannot be interpreted.

2. Love withdrawal has a negative coefficient of -

0.034 and a value of $t=-0.317$. These results indicate that love withdrawal is not significant for the self-compliance of down syndrome children. Thus this result cannot be interpreted.

3. Induction has a positive coefficient of 0.086 and a value of $t=0.754$. These results indicate that induction is not significant for self-compliance of down syndrome children. Thus this result cannot be interpreted.

4. Maternal self efficacy after training in traditional game benefits has a positive coefficient of 0.526 and a value of $\mathrm{t}=4.631$, where the higher the mother's self efficacy in understanding the benefits of traditional games, in this case, the example is crank play can improve children's verbal abilities so they can significantly improve self-compliance of down syndrome children. 
Table 2.

R. Square

\begin{tabular}{lccccc}
\hline $\begin{array}{c}\text { Observed } \\
\text { Variable }\end{array}$ & Coefficient & S.E. & t value & $\begin{array}{c}\text { Two- } \\
\text { Tailed } \\
\text { P-Value }\end{array}$ & Sig \\
\hline $\begin{array}{l}\text { Verbal } \\
\text { ability }\end{array}$ & 0.347 & 0.149 & 2.333 & 0.020 & $\sqrt{ }$ \\
$\begin{array}{l}\text { Self } \\
\text { obedience }\end{array}$ & 0.859 & 0.334 & 2.573 & 0.010 & $\sqrt{ }$ \\
\hline
\end{tabular}

In table 2, the R-Square value shows that verbal ability with power assertion, love withdrawal, induction and the ability of the mother can explain the self-obedience of Down syndrome children by 0.859 . While 0.347 variants of verbal abilities can be explained by the four variables, namely the technique of parental discipline consisting of three dimensions (power assertion, love withdrawal, and induction) and the ability of the mother. In the research model, the results of this modification have also been shown to have direct and indirect effects of IV on DV. The results of the calculation of the direct and indirect effects of the calculation of the modified research model are as follows:

Table 3.

Indirect Impact

\begin{tabular}{|c|c|c|c|c|c|c|}
\hline $\begin{array}{l}\text { The impact of } \\
\text { disciplinary } \\
\text { techniques and the } \\
\text { mother's ability to } \\
\text { self-compliance }\end{array}$ & Via & $\begin{array}{c}\text { Coeffic } \\
\text { ient }\end{array}$ & S.E. & $t$ value & $\begin{array}{c}\text { Two- } \\
\text { Tailed } \\
\text { P- } \\
\text { Value }\end{array}$ & Sig \\
\hline $\begin{array}{l}\text { Specific Indirect } \\
\text { Power assertion } \\
\text { Love withdrawal } \\
\text { Induction } \\
\text { mother ability }\end{array}$ & $\begin{array}{l}\text { Verbal } \\
\text { ability }\end{array}$ & $\begin{array}{c}-0 .-018 \\
-0.032 \\
0.080 \\
0.521\end{array}$ & $\begin{array}{l}0.100 \\
0.100 \\
0.100 \\
0.085\end{array}$ & $\begin{array}{c}-0.181 \\
-0.315 \\
0.800 \\
6.094\end{array}$ & $\begin{array}{l}0.856 \\
0.752 \\
0.424 \\
0.000\end{array}$ & $\begin{array}{l}X \\
X \\
X \\
V\end{array}$ \\
\hline
\end{tabular}

Note: $\sqrt{ }$ : siginificant; $x$ : not significant

In table 3, it can be seen that the mother's ability has an indirect impact on the selfcompliance of Down syndrome children. While the variable power assertion, love withdrawal, and induction do not have an indirect impact on self-compliance of Down syndrome children. 


\section{Discussion}

Based on the results of statistical tests, it can be concluded that:

1. Model - the influence of traditional disciplinary techniques and games through verbal ability to adhere to children with Down syndrome - fit with the data. This means that the model in which power assertion, love withdrawal, and induction is part of the parent discipline technique, and the mother's ability after attending the seminar the benefits of traditional games affect the self- adherence of children with Down syndrome, where the child's verbal ability, picture naming, and receptive vocabulary can be declared fit $($ Chi-Square $=11,410, \mathrm{df}=8, \mathrm{P}$-value $=0.1795, \mathrm{RMSEA}=0.073)$.

2. There is no direct influence of disciplinary techniques and the ability of parents to give orders after attending traditional game training on adherence to children with Down syndrome. This means that there are mediator variables that mediate the influence of disciplinary techniques and the ability of parents to give orders after attending traditional game training on adherence to children with Down syndrome.

3. There are no indirect or direct effects of parental discipline techniques on adherence to children with Down syndrome. This means that the variable power assertion, love withdrawal, and induction do not have a direct or indirect impact on the self-compliance of Down syndrome children.

4. There is a significant influence on the ability of the mother to give orders (after training in traditional games) towards adherence to the verbal abilities of children with Down syndrome. This means that maternal self-efficacy has an indirect impact on selfcompliance of Down syndrome children.

5. Verbal ability possessed by children with Down syndrome can predict the level of adherence to children

Based on the results of data analysis, it can be seen that verbal abilities (both receptive and expressive abilities) can mediate the influence of maternal self- efficacy in giving orders to the level of compliance with Down syndrome children. This is in line with the study of Cuskelly and colleagues [17] which shows that respondents who have high language skills can carry out orders to wait for the gift they want. This research was also proven in recent studies that showed that language skills, especially receptive language, affect the ability of respondents to delay according to instructions given [9]. The findings in this study reflect the importance of language skills especially receptive language.

In this study, both receptive language $(\mathrm{p}=0.020)$ and expressive language $(\mathrm{p}=$ 0.038 ) had a significant influence on the level of adherence to Down syndrome children. This finding reflects that language skills can predict the level of compliance. Children with Down syndrome (ds) who have good language skills, especially receptive language, can understand the commands or instructions given. Whereas children with Down syndrome (ds) who have low language skills, will experience difficulties when receiving simple commands or instructions. They do not understand the contents of orders or instructions given so they tend to do things that are following their wishes. This is what 
makes people around them rate them not obedient, meaning that they do not want to follow orders or instructions conveyed by others, in this case, are parents (mother).

In this study, preliminary data shows a pattern of interaction between mothers and children that seems less effective, where some participants choose to give gadgets or let their children find their activities, if there are mother's interaction more distracting children by asking them to play, mothers are less informed used by children to direct their behavior. In this study, the training provided focused on how to interact effectively by utilizing traditional games.

The findings in this study indicate that after training in giving instructing with traditional game media the ability of maternal self-efficacy had a significant direct influence on the level of adherence and through verbal ability $(p=0.526 ; t=4.631)$. Training in providing instruction with traditional game media can improve the quality of orders (requests) where parents can give orders clearly, calmly and specifically. Clear, calm and specific orders will increase compliance [16]. Parents who are taught to give orders effectively through several pieces of trainings will improve children's needs. In this study, the intervention given is the way of giving orders through traditional games assumed to increase the level of compliance.

The disciplinary technique in this study did not have a significant effect either directly or indirectly on adherence to children with Down syndrome. This means that the variable power assertion, love withdrawal, and induction do not have a direct or indirect impact on the self-compliance of Down syndrome children. This finding is different from the results of the study of Schaffer and Crook [18] in children from lower socio-economic age- aged 15 months and 24 months, stating that disciplinary techniques influence the level of adherence to children. The research conducted by Sumiati [4] parenting (power assertion, love withdrawal, and induction) does not have a significant influence on the behavior problem in children with Down syndrome. Research results from Sumiati and colleagues (2017) show that the same thing, namely parenting (power assertion, love withdrawal, and induction) does not have a significant effect on the level of independence of children with Down syndrome. The findings of the research by Sumiati [4] and Sumiati and colleagues (2017) are in line with this study. Thus, parenting or disciplinary techniques (power assertion, love withdrawal, and induction) in children with Down syndrome do not influence their behavior including the level of independence and compliance. This is different from the results of the study in children typically development (TD). This finding reflects that in Down syndrome children need different parenting styles or disciplines to form optimally expected behaviors.

The findings in this study reflect the need for further research that can prove and find parenting or an effective discipline technique for children with Down syndrome. Research on parenting or disciplinary techniques appropriate for children with Down syndrome is needed so parents can accompany them and optimize their potential better. 


\section{Suggestion}

\section{Theoretical Suggestions}

The theoretical suggestions that can be delivered based on the results of this study are

1. Due to the limited number of research respondents who have special characteristics, namely mothers and children with Down syndrome, it is expected that in similar studies to come, can expand the area of respondents' coverage and expand the network with organizations that protect the activities of children with Down syndrome, so as to obtain more respondents

2. For the parents' disciplinary technique variables in this study using the concept of parental discipline techniques in general applies. However, it is hoped that future research can use more typical concepts used in explanations to adapt to the characteristics of children with Down syndrome.

3. In similar advanced research, it is expected to be able to use traditional game concepts with other variations so that they can expand the concept of traditional games.

4. Because of the peculiarities of the characteristics of the respondents, it is expected that in future studies can make age criteria that have a more specific range.

\section{Practical Suggestion}

For practical advice, this will be given to parents, especially mothers and children with Down Syndrome itself. The practical suggestions are:

1. Parents are expected to be able to apply and use the techniques and abilities they have based on the results of traditional game training provided within the scope of this study, so they can develop and improve Down syndrome children's compliance with simple instructions.

2. It is expected that children with Down syndrome can increase their adherence by following the procedures given in this study, including children who can improve their verbal abilities especially receptive to being more obedient in carrying out the commands of God.

3. For governments and relevant agencies in developing and developing the abilities of down syndrome children, especially in terms of compliance with simple instructions, it is hoped that they can use the results of this study as a reference for making modules and programs for the formation, formation, and improvement of compliance with children with Down syndrome.

4. For parents, teachers and related institutions are expected to be able to use traditional games as learning media for increasing adherence to children with Down syndrome. 


\section{References}

[1] Gameren-oosterom, H. B. M. Van, Fekkes, M., Buitendijk, S. E., Mohangoo, A. D., \& Wouwe, J. P. Van. (2011). Development, Problem Behavior, and Quality of Life in a Population-Based Sample of Eight-Year-Old Children with Down Syndrome, 6(7), 1620. http://doi.org/10.1371/journal.pone.0021879

[2] Grieco, J., Pulsifer, M., Seligsohn, K., \& Skotko, B. (2015). Down Syndrome : Cognitive and Behavioral Functioning Across the Lifespan, 149(May), 135-149. http://doi.org/10.1002/ajmg.c.31439

[3] Coe, D.A.; Matson, J.L.; Russell, D.W.; Slifer, K.J.; Capone, G.T.; Baglio, Ch., \& Stalings. S. (1999). Behavior problems of children with Down syndrome and life events. Journal of Autism and Developmental Disorders. 29(2)

[4] Sumiati, N.T. (2014). Hubungan antara family belief systems dan tipe pola asuh terhadap behavior problems anak dengan down syndrome. Tazkia

[5] Radley, K.C., Dart, E.H. (2016). Antecedent Strategies to Promote Children's and Adolescents' Compliance with Adult Requests: A Review of the Literature. Clin Child Fam Psychol Rev, 19, 39-54. DOI 10.1007/s10567-015-0197-3

[6] Hoffman, M. L., \& Saltzstein, H. D. (1967). Parent discipline and the child's moral development. Journal of Personality and Social Psychology, 5, 45-57

[7] Shabrina, R. (2014). Pengaruh parenting self-efficacy dan kekuatan karakter terhadap tipe pola asuh pada ibu dengan anak berkebutuhan khusus. Skripsi Fakultas Psikologi UIN Jakarta.

[8] Singer, B., \& Bashir, a. (1999). What are executive functions and self-regulation and what do they have to do with language-learning disorders? Language, Speech, and Hearing Services in Schools, 30(3), 265-273. http://doi.org/10.1016/j.tics.2012.01.006

[9] Cuskelly, M., Gilmore, L., Glenn, S., \& Jobling, A. (2016). Delay of gratification: A comparison study of children with Down syndrome, moderate intellectual disability, and typical development, d,865-873. http://doi.org/10.1111/jir.12262

[10] Ritzi, R.M.; Ray, D.C., \& Schummann, B.R. (2017). Intensive Short-Term ChildCentered Play Therapy and Externalizing Behaviors in Children. International Journal of Play Therapy,26 (1),33-46. http://dx.doi.org/10.1037/pla0000035.

[11] Landreth L. G., (2012), Plat Therapy: The Art of The Relationship, New York, Routledge Taylor \& Francis Group 
[12] Beiberich, A.A., \& Morgan, S.B. (2004). Self-Regulation and Affective Expression During Play in Children with Autism or Down Syndrome: A Short-Term Longitudinal Study. Journal of Autism and Developmental Disorders, 34 (4).

[13] Vieillevoye, S. \& Nader-Grosbois, N. (2008). Self- regulation during pretend play in children with intellectual disability and in normally developing children. Research in Developmental Disabilities, 29, 256-272

[14] Singh, S.J., Iacono, T. \& Gray. K.M. (2014). An Investigation of the Intentional Communication and Symbolic Play Skills of Children With Down Syndrome and Cerebral Palsy in Malaysia. Journal of Early Intervention, 36(2) 71-89. DOI: $10.1177 / 1053815114562044$

[15] Rodriguez, Ch.M. (2015). Parental discipline reactions to child noncompliance and compliance: Association with parent-child aggression indicators. Journal Child Fam Stud 25, 1363-1374

[16] Schueler, Ch.M. \& Prinz, R.J. The Role of Caregiver Contingent Responsiveness in Promoting Compliance in Young Children. Child Psychiatry Hum Dev. 44,370-381.

DOI 10.1007/s10578-012-0331-0

[17] Cuskelly,M., Zhang, A., \& Hayes, A. (2003). A Mental Age-Matched Comparison Study of Delay of Gratification in Children with Down Syndrome. International Journal of Disability, Development, and Education, 50(3), 239-251. DOI: 10. 1080/ J 034912032000120435

[18] Schaffer, H.R, Crook, Ch.K. (1980). Child Compliance and Maternal Control Techniques. Developmental Psychology, 16 (1), 54-61.

[19] Birth Defects In South-east Asia A Public Health Challenge. (n.d.).

[20] Brooks B J. (2011), The Process of Parenting, New York, McGraw-Hill

[21] Dlugokinski, E. L., \& Firestone, I. J. (1974). Other centeredness and susceptibility to charitable appeals: Effects of perceived discipline. Developmental Psychology, $10(1), 21$.

[22] Davidson, J. E. (2014) Supporting Student with Special Health Care Needs, New York, Brookes Publishing

[23] Dix, T. (1991). The affective organization of parenting: Adaptive and maladaptive processes. Psychological Bulletin, 110(1), 3-25.

[24] Fidler, D. J. (2005). The Emerging Down Syndrome Behavioral Phenotype in Early Childhood. Infants \& Young Children, 18(2), 86-103. http://doi.org/10.1097/00001163-200504000- 00003 
[25] Hoffman, M.L. (1963) Parent discipline and the child's consideration for others. Child Development, 34, 573-588.

[26] Hoffman, M.L. (1963). Childrearing practices and moral development: Generalizations from research. Child Development, 34, 295-318.

[27] Hoffman, M.L. (1983). Affective and cognitive processes in moral internalization. In E. T. Higgins, D. N. Ruble \& W. W. Hartup (Eds.), Social cognition and social development (pp.236-274). Cambridge, England: Cambridge University Press.

[28] Landreth G. \& Kidron M., (2010), Intensif child-parent relationship therapy with Israeli Parent in Israel, International Journal of Play Therapy. 19 (2), 64-78

[29] Patterson, D., \& Costa, A. C. S. (2005). The early history of Down syndrome. Genetics, 6(February), 137- 147. http://doi.org/10.1038/nrg1525

[30] Pinter, J. D., Eliez, S., Schmitt, J. E., Capone, G. T., \& Reiss, A. L. (2001). Neuroanatomy of Down's Syndrome: A High-Resolution MRI Study. AM Psychiatry, 58,1659-1665. http://doi.org/10.1210/jc.2007-2734

[31] Roubertoux, P. L., \& Kerdelhue, B. (2006). Trisomy 21: From Chromosomes to Mental Retardation, 36(3), 346-355. http://doi.org/10.1007/s10519-006-9052-0

[32] Scarlett, G W. (2005), Children's Play, USA, Sage Publication

[33] Schaefer, C. E., (2016), Essential Play Therapy Techniques; Time-Tested Approaches, New York, Guilford Press

[34] Van der Mark, I.L., Bakermans-Kranenburg, M. J., Van Ijzendoorn, M. H., (2002). The role of parenting, attachment, and temperamental fearfulness in the prediction of compliance in toddler girls. The British Journal of Developmental Psychology, 20,361-378.

[35] Xiao, Xinyue, "Inductive Discipline and Children's Prosocial Behavior: the Role of Parental Emotion Regulation Strategies" (2016). Dissertations - ALL. Paper 507. 